\title{
KADAR HEMOGLOBIN DAN UJI TOURNIQUET PADA PASIEN ANAK DENGAN INFEKSI VIRUS DENGUE DI MANADO
}

\author{
${ }^{1}$ Joseph Hardi \\ ${ }^{2}$ Glady Rambert \\ ${ }^{2}$ Firginia Manoppo
}

\author{
${ }^{1}$ Kandidat Skripsi Fakultas Kedokteran Universitas Sam Ratulangi Manado \\ ${ }^{2}$ Bagian Patologi Klinik Fakultas Kedokteran Universitas Sam Ratulangi Manado \\ Email: joseph.leli@yahoo.com
}

\begin{abstract}
Dengue infection is a systemic and dynamic disease that has a broad spectrum. The key for good management and results is to know and understand arising signs. Various examination is necessary for diagnosis, one of them are the examination of hemoglobin levels and tourniquet test. This research was a cross sectional study. Samples were obtained from 37 pediatric patients with dengue virus infection of the total population sample of 72 patients in RS Advent Manado, RSU GMIM Pancaran Kasih Manado, and RSAD Robert Wolter Mongisidi Teling. The results of this study show the hemoglobin levels on pediatric patients with dengue virus infection mostly in normal levels and not all patients show positive tourniquet test results.
\end{abstract}

Keywords: dengue, hemoglobin levels, tourniquet test

\begin{abstract}
Abstrak: Infeksi dengue adalah suatu penyakit sistemik dan dinamik yang memiliki spektrum yang luas. Kunci keberhasilan dalam pengelolaan dan hasil yang baik adalah mengenal dan memahami tanda-tanda yang timbul. Diperlukan berbagai pemeriksaan penunjang salah satu diantaranya adalah pemeriksaan kadar hemoglobin dan uji tourniquet. Penelitian ini merupakan penelitian cross sectional. Sampel penelitian diperoleh 37 pasien anak dengan infeksi virus dengue dari total populasi sampel 72 pasien di RS Advent Manado, RSU GMIM Pancaran Kasih Manado, dan RSAD Robert Wolter Mongisidi Teling. Hasil penelitian menunjukkan gambaran hemoglobin pada pasien anak dengan infeksi virus dengue sebagian besar dalam kadar normal dan tidak semua menunjukkan uji tourniquet positif.
\end{abstract}

Kata kunci: dengue, kadar hemoglobin, uji tourniquet

Demam dengue (DD), demam berdarah dengue (DBD), dan dengue shock syndrome (DSS) adalah penyakit akibat infeksi virus dengue yang masih menjadi perhatian dunia kesehatan internasional. ${ }^{1}$ Sekitar 1,8 milyar atau lebih dari 70\% dari populasi yang berisiko DBD tinggal di Asia tenggara. ${ }^{2}$ Sebanyak 90\% kasus DBD yang terjadi di Indonesia menyerang anak dibawah 15 tahun. $^{3}$ Kasus DBD di kota Manado pada tahun 2013 sebanyak 410 kasus (IR 100,40 per 100.000 penduduk) dengan 4 kematian (CFR 0,98\%) dan 255 kasus (IR 62,45 per 100.000 penduduk) dengan 10 kematian (CFR 3,92\%) sampai bulan Agustus 2014. ${ }^{4}$ Penyakit DBD cenderung meningkat dalam beberapa tahun terakhir dan menyerang anak-anak di Sulawesi Utara. ${ }^{5}$

Infeksi dengue adalah suatu penyakit sistemik dan dinamik yang memiliki spektrum luas. Setelah masa inkubasi, penyakit dimulai secara mendadak diikuti oleh tiga fase penyakit yaitu fase demam, fase kritis, dan fase penyembuhan. Kunci keberhasilan dalam pengelolaan dan hasil 
yang baik adalah mengenal dan memahami tanda-tanda yang yang timbul selama fasefase tersebut. ${ }^{2}$ Diperlukan berbagai pemeriksaan penunjang salah satu diantaranya adalah pemeriksaan kadar hemoglobin yang dapat dilakukan untuk membantu dalam diagnosis infeksi dengue dan menentukan prognosis dari pasien tersebut.

Kadar hemoglobin pada awal perjalanan penyakit biasanya normal atau sedikit menurun. Tetapi kemudian kadarnya akan naik mengikuti peningkatan keadaan hemokonsentrasi dan merupakan kelainan hematologi paling awal yang ditemukan pada kasus DBD. ${ }^{6}$

Terdapat sejumlah tes yang cepat untuk mendiagnosa infeksi virus dengue, termasuk tes imunokromatografik dan polymerase chain reaction. Biaya menjadi hambatan dalam adopsi skala luas dari tes di daerah-daerah miskin dan kurang mendapat pelayanan yang sering terkena infeksi dengue. Oleh karena itu, diagnosis dan klasifikasi mengandalkan sarana yang lebih mudah didapatkan dengan harga terjangkau.

$\begin{array}{crrr}\text { Uji tourniquet } & \text { adalah teknik } \\ \text { pemeriksaan fisik } & \text { yang dapat }\end{array}$ mengidentifikasi dan mengelompokkan penyakit dengue. Infeksi DENV dapat mengakibatkan peningkatan permeabilitas kapiler, keadaan fisiologis yang dapat ditunjukkan uji tourniquet dengan memberi tekanan terus-menerus pada pembuluh kecil. Petekie yang dihasilkan dapat ditemukan pada pasien dengan DD atau DBD. ${ }^{7}$

\section{METODE PENELITIAN}

Penelitian ini merupakan penelitian cross sectional. Sampel penelitian diperoleh 37 pasien anak dengan infeksi virus dengue dari total populasi sampel 72 pasien di RS Advent Manado, RSU GMIM Pancaran Kasih Manado, dan RSAD Robert Wolter Mongisidi Teling. Hasil penelitian diolah dan disusun menggunakan program Microsoft Office Word dan Microsoft Office Excel.

\section{HASIL PENELITIAN DAN BAHASAN}

Berdasarkan data yang diperoleh, pasien infeksi dengue yang memiliki kadar hemoglobin rendah sebanyak 7 orang (18.9\%), kadar hemoglobin normal sebanyak 24 orang (64.9\%), dan kadar hemoglobin tinggi sebanyak 6 orang (16.2\%). Jumlah pasien terbanyak yaitu pasien yang memiliki kadar hemoglobin normal. Kadar hemoglobin pada hari ketiga, keempat, dan kelima menunjukkan gambaran hasil terbanyak pada kadar normal sebanyak 14 orang (66.67\%), 5 orang (55.56\%), dan 5 orang (71.4\%). Hal ini sesuai dengan teori bahwa kadar hemoglobin pada hari-hari pertama biasanya normal atau sedikit menurun, tetapi kemudian kadarnya akan naik mengi kuti peningkatan hemokonsentrasi dan merupakan kelainan hematologi paling awal yang ditemukan pada DBD.

Tabel 1. Hasil pemeriksaan kadar hemoglobin.

\begin{tabular}{|c|c|c|c|c|c|c|}
\hline \multicolumn{7}{|c|}{ Kadar Hemoglobin } \\
\hline \multirow[b]{2}{*}{ Variabel } & \multicolumn{2}{|c|}{ Rendah } & \multicolumn{2}{|c|}{ Normal } & \multicolumn{2}{|c|}{ Tinggi } \\
\hline & $\mathrm{n}$ & $\%$ & $\mathrm{n}$ & $\%$ & $\mathrm{n}$ & $\%$ \\
\hline $\begin{array}{l}\text { Umur (th) } \\
0.5-2 \\
\text { (rentang) }\end{array}$ & 0 & 0 & 1 & 100 & 0 & 0 \\
\hline $\begin{array}{l}2-6 \\
\text { (rentang) }\end{array}$ & 1 & 11,1 & 6 & 66,7 & 2 & 22,2 \\
\hline $\begin{array}{l}6-12 \\
\text { (rentang) }\end{array}$ & 3 & 20 & 10 & 66,7 & 2 & 13,3 \\
\hline $\begin{array}{l}12-14 \\
\text { (rentang) }\end{array}$ & 3 & 25 & 7 & 58,3 & 2 & 16,7 \\
\hline \multicolumn{7}{|l|}{$\begin{array}{l}\text { Jenis } \\
\text { Kelamin }\end{array}$} \\
\hline Laki-Laki & 4 & 23.5 & 9 & 53 & 4 & 23,5 \\
\hline Perempuan & 3 & 15 & 15 & 75 & 2 & 10 \\
\hline \multicolumn{7}{|l|}{ Pemeriksaan } \\
\hline $\begin{array}{l}\text { NS1 } \\
\operatorname{IgG~(+)~/~}\end{array}$ & 4 & 18,2 & 14 & 63,6 & 4 & 18.2 \\
\hline $\begin{array}{l}\operatorname{IgM}(-) \\
\operatorname{IgG}(-) /\end{array}$ & 3 & 21,4 & 9 & 64,3 & 2 & 14.3 \\
\hline $\operatorname{IgM}(+)$ & 0 & 0 & 1 & 100 & 0 & 0 \\
\hline \multicolumn{7}{|l|}{$\begin{array}{l}\text { Demam hari } \\
\text { ke- }\end{array}$} \\
\hline 3 & 3 & 14,3 & 14 & 66,7 & 4 & 19,0 \\
\hline 4 & 3 & 33,3 & 5 & 55,6 & 1 & 11,1 \\
\hline 5 & 1 & 14,3 & 5 & 71,4 & 1 & 14,3 \\
\hline
\end{tabular}


Peningkatan nilai hematokrit merupakan manifestasi hemokonsentrasi yang terjadi akibat kebocoran plasma ke ruang ekstravaskular disertai efusi cairan serosa, melalui kapiler yang rusak. Kebocoran ini mengakibatkan volume plasma menjadi berkurang dan dapat mengakibatkan terjadinya syok hipovolemik dan kegagalan sirkulasi. ${ }^{6}$

Hasil uji tourniquet menunjukkan 20 orang (54\%) memiliki jumlah petekie lebih dari 10 dan 17 orang (46\%) memiliki jumlah petekie kurang dari sama dengan 10 (Tabel 2).

Tabel 2. Hasil pemeriksaan jumlah petekie

\begin{tabular}{|c|c|c|c|c|}
\hline \multicolumn{5}{|c|}{ Jumlah Petekie } \\
\hline \multirow[t]{2}{*}{ Variabel } & \multicolumn{2}{|c|}{$>10$} & \multicolumn{2}{|c|}{$\leq 10$} \\
\hline & $\mathrm{n}$ & $\%$ & $\mathrm{n}$ & $\%$ \\
\hline \multicolumn{5}{|l|}{ Umur (th) } \\
\hline $0.5-2$ (rentang) & 0 & 0 & 1 & 100 \\
\hline 2- 6 (rentang) & 3 & 37,5 & 5 & 62,5 \\
\hline $6-12$ (rentang) & 11 & 68,75 & 5 & 31,25 \\
\hline $12-14$ (rentang) & 6 & 50 & 6 & 50 \\
\hline \multicolumn{5}{|l|}{ Jenis Kelamin } \\
\hline Laki-Laki & 9 & 52,9 & 8 & 47,1 \\
\hline Perempuan & 11 & 55,0 & 9 & 45,0 \\
\hline \multicolumn{5}{|l|}{ Pemeriksaan } \\
\hline NS1 & 15 & 68,2 & 7 & 31,8 \\
\hline $\operatorname{IgG}(+) / \operatorname{IgM}(-)$ & 4 & 28,6 & 10 & 71,4 \\
\hline $\operatorname{IgG}(-) / \operatorname{IgM}(+)$ & 1 & 100 & 0 & 0,0 \\
\hline \multicolumn{5}{|l|}{ Demam hari ke- } \\
\hline 3 & 15 & 71,4 & 6 & 28,6 \\
\hline 4 & 3 & 33,3 & 6 & 66,7 \\
\hline 5 & 2 & 28,6 & 5 & 71,4 \\
\hline
\end{tabular}

Hasil uji tourniquet yang positif dapat disebabkan karena infeksi virus dengue menyebabkan aktivasi makrofag yang memfagositosis kompleks virus-antibodi non netralisasi sehingga virus bereplikasi di makrofag. Terjadinya infeksi makrofag oleh virus dengue menyebabkan aktivasi $T$ helper dan T-cytotoxic sehingga diproduksi limfokin dan interferon gamma (IFN- $\gamma$ ). Interferon gamma akan mengaktivasi monosit sehingga disekresi berbagai mediator inflamasi seperti TNF- $\alpha$, IL-1, PAF (platelet activating factor), IL-6 dan histamin yang mengakibatkan terjadinya disfungsi sel endotel dan terjadi kebocoran plasma. $^{8}$

Berdasarkan penelitian yang dilakukan Phuong et al. sensitifitas uji ini sebesar $46.2 \%$ dengan spesifisitas mencapai 84.5\%. Kelemahan dari uji ini adalah hasil negatif tidak dapat diinterpretasikan bahwa orang tersebut tidak terkena infeksi dengue karena spesifitas yang tinggi tetapi sensitifitas yang rendah. ${ }^{9}$ Namun uji ini masih dapat digunakan untuk diagnosis dan klasifikasi dengue di daerah perifer yang kurang mendapat pelayanan dan sering terkena infeksi dengue karena lebih mudah didapatkan dengan harga terjangkau.

\section{SIMPULAN}

Berdasarkan hasil penelitian dan pembahasan diatas, disimpulkan bahwa gambaran hemoglobin pada pasien anak dengan infeksi virus dengue sebagian besar dalam kadar normal dan tidak semua menunjukkan uji tourniquet positif.

\section{SARAN}

Penelitian ini dapat dikembangkan pada penelitian selanjutnya dengan mencari hubungan antara kadar hemoglobin dan lama demam agar mendapatkan gambaran kadar hemoglobin yang lebih lengkap pada pasien dengue.

\section{DAFTAR PUSTAKA}

1. World Health Organization. Comprehensive Guidelines for Prevention and Control of Dengue and Dengue Hemorrhagic Fever. India. 2011; h.11.

2. World Health Organization. Dengue Guidelines For Diagnosis, Treatment, Prevention and Control. Switzerland. 2009; p.25.

3. Hakim L, Kusnandar AJ. Hubungan jumlah dan kepadatan penghuni rumah serta keberadaan nyamuk dengan frekuensi menggigit nyamuk Aedes aegypti saat mencari darah di 
Kabupaten Cirebon Provinsi Jawa Barat. Aspirator 2010;2:92-8.

4. UPTD Balai Data, Surveilans \& SIK. Jumlah penderita dan kematian penyakit DBD tahun 2013/2014 di propinsi Sulawesi Utara. 2014.

5. Gunawan S, Sutanto FC, Tatura SN, Mantik MF. Platelet distribution width dan mean platelet volume: hubungan dengan derajat penyakit demam berdarah dengue. Sari Pediatri 2010;12:74-7.

6. Rena NM, Utama S, Parwati T. Kelainan hematologi pada demam berdarah dengue. J Peny Dalam 2009;10:21825.

7. Halsey E, Vilcarromero S, Forshey B,
Rocha C, Bazan I, et al. Performance of the tourniquet test for diagnosing dengue in peru. Am J Trop Med Hyg 2013:89:99-104.

8. Sudoyo AW, Setiyohadi B, Alwi I, Simadibrata M, Setiadi S. Buku Ajar Ilmu Penyakit Dalam Jilid III (Edisi Keempat). Jakarta: Interna Publishing, 2006; p.1709-13.

9. Cao XT, Nhan NT, Wills B, Kneen R, Ha Nt, Mai TT et al. Evaluation of the World Health Organization standard tourniquet test and a modified tourniquet test in the diagnosis of dengue infection in Viet Nam. Trop Med Int Health 2002:2:125-32. 